- Kitap İncelemeleri.Book Reviezus-

\title{
Estetik ve Sinema
}

\author{
İnceleyen: Firat Osmanoğulları
}

\author{
Yazar: Sarper Bütev \\ Neyno Kültür Yayınları, Kastamonu: 2021, 96 s. \\ ISBN: 978-605-70630-1-4
}

\section{Özet}

Sarper Bütev'in 'Estetik ve Sinema' adlı kitabı, estetiğin ne olduğunu, tarih boyunca hangi dönüşümlere uğradığını ortaya koyarak, en sonunda sinemanın nasıl bir estetik deneyim sunduğu sorusu üzerinde yoğunlaşıyor. Çalışma, estetiğin, en temelde, geçekliğin duyular ve duyular yoluyla algılanışı; bir yandan da sanat yapıtları üzerine bir düşünme faaliyeti olması üzerinden kendisini inşa ediyor.

Kitap, birçok düşünürün estetik ve sanat üzerine geliştirdiği düşünceleri, ardından da sinemanın bir sanat olarak kabul görme sürecinden itibaren ortaya çıkan temel yaklaşımları derli toplu olarak sunmasıyla önemli bir işlevi yerine getiriyor. İkinci olarak, Kant ve Hegel gibi çetrefilli eserler vermiş olan düşünürler de dâhil olmak üzere, düşünürlerin estetik kavrayışlarını, olabildiğine yalın ve anlaşılır bir dille ortaya koyuyor. Son olarak, kitabın estetik üzerine olan yaklaşımları ortaya koyarken takip ettiği, büyük ölçüde kronolojik yol sayesinde, estetik kavramının geçirdiği dönüşümlerin izini sürmek, okuyucu için oldukça kolaylaşıyor. Dolayısıyla kitap, anlatmak istediklerini okuyanın zihnini yormadan, kısa ve net ifadelerle, lafı uzatmadan ve gereğinden fazla karmaşıklaştırmadan anlatıyor. Bunu yapabilmesiyle, yazarın hem konuya hem de kitap içerisinde yer verilen düşünürlerin eserlerine ve felsefelerine hâkim olduğunu net bir şekilde gösteriyor. Tüm bunlardan hareketle kitabın, hem sinema öğrencileri hem estetik ve sanat meselelerine ilgi duyanlar hem de bu konulara yeni giriş yapacaklar için uygun bir kaynak olduğunu söylemek mümkün.

Kitabın ilk bölümünde önce, estetiği özerk bir alan olarak ele almaktan uzak, sanatı mimetik niteliği ile sınırlayan, onu taklitten ibaret gören Platon, Aristoteles, Plotinos gibi Grek filozofların yaklaşımları üzerinde durulmuştur. Platon'un estetik üzerine olan görüşlerinin açılandığı bölüme göre Platon, sanatsal faaliyeti, gerçekliği çarpıtan bir yanılsama, doğanın aşağı düzeyde bir taklidi (hatta taklidin taklidi) olarak ele almıştır. Ona göre sanat, insanları gerçeklikten uzaklaştırmakta, yoldan çıkarmaktadır. Bu sebeple de, onun Devlet'inde, eğer politik ve ahlaki bir yarar sağlamıyorsa, sanata büyük ölçüde yer yoktur. Ancak diğer yandan, başka eserlerinde Platon sanatı, bir yaratma/poesis etkinliği olarak, sanatçıyı ise poietas/ yaratıcı olarak görmüştür. Platon' un öğrencisi Aristoteles de, tıpkı hocası gibi, sanatsal faaliyeti bir mimesis olarak ele almıştır. Bununla birlikte, ondan farklı olarak sanatı politik ve ahlaki bir yarar sağlaması üzerinden değil, bir 'bilme' etkinliği olarak değerlendirmiştir. Ancak Aristoteles için sanatın bir psikolojik işlevi de vardır: katharsis ya da arınma. Fakat Aristoteles de, estetiği bağımsız bir alan olarak kurmaya çalışmamış, Platon gibi etik bir mesele olarak ele almıştır. Yeni Platonculuğun kurucu filozofu Plotinos ise, sanatın görünüşü değil; özü, ideaları taklit ettiğini savunmakla birlikte, Platon'un anlayışını büyük ölçüde sürdürmüştür. Neticede Grekler estetiği, zihin ve mantığın kavradığı bilgiden daha aşağı düzeyde bir bilgi 
türü olarak görmüşlerdir. Ortaçağ' daki hâkim estetik anlayış da Yeni Platonculuğun etkisi altındadır; güzellik dinsel, metafizik bir unsur olarak, Tanrının varlığının bir işareti olarak değerlendirilmiştir.

On sekizinci yüzyılda ise amprizmin yükselişiyle beraber, bilginin kaynağına ulaşmada akıldan çok, duyular ön plana çıkmıştır. Bu durum, estetiğin itibar kazanmasını sağlamıştır. İngiltere'de Shaftesbury, Hutcheson, Hume gibi düşünürler, güzel olanı, yararlı, iyi, gerçek gibi kavramlarla birlikte ele almaya devam ettiklerinden dolayı özerk bir estetik alanı kuramamışlar. Fakat bunu, Alman estetik düşünürleri başarmışlardır.

Alman düşünür Baumgarten, bağımsız bir felsefe dalı olarak estetik alanı oluşturmaya çalışmıştır. Ona göre estetik, duyusal olarak elde edilen bilgidir. Duyular yolu ile elde edilen bilginin bulanıklığını gidermek ise, estetiğin temel amacıdır. Ancak, yine de, Baumgarten için estetik gerçeklik, mantık ve düşünce yoluyla kavranan bilginin daha aşağı bir düzeyde yer almıştır.

Estetiği özerk bir alan olarak kurmayı başarmış Alman filozof ise Kant'tır. Kant'a göre, öznenin, dünyadaki şeyler ile ilgilenmesi, sadece onları bilmek ve onlardan yararlanmak ile sınırlı değildir; özne onları haz veren ya da vermeyen şeyler olarak da deneyimler ve kendisinde bıraktığı etkiye göre de bir yargıya varır. Bu yargılama yetisi beğeniye karşılık gelir ve beğeninin eleştirisi ise estetiğin kendisidir. Beğeni; o şeyi hiçbir çıkar olmaksızın hoşlanma ya da hoşlanmama yoluyla yargılama yetisidir. Bir nesneden, çıkar gütmeden hoşlanıyorsam o güzeldir. Doğanın kendi içinde ne olduğu, ereğinin ne olduğu insan bilgisine kapalıdır; doğa, kendisini ancak güzellik olarak insana açar ve bu sebeple de bir hoşlanmanın konusu olabilir. Özne, dünyayı duygular yoluyla özerk bir biçimde deneyimler; onda yarattığı hoşlanma ya da hoşlanmama yoluyla bir beğeni yargısında bulunur.

Sanat yapıtında ise, yaratım sürecinde akıl ve irade de devreye girer; tinsel bir yaratım. Kant bu noktada, sanatı mimesis olmanın ötesinde ele alır. Çünkü sanatçı, yaratım sürecinde, materyali ne olursa olsun, onu biçimlendirmekte, dönüştürmektedir. Gerçekliği; ikinci bir gerçekliğe dönüştürür. Sanat yapıtı gerçekliği aşar; doğada olmayan bir fazlalık üretir. Bu sebeple bir dehanın ürünüdür. Bu yeteneğe (estetik ideaları sergileme yeteneği) sahip kişi ise deha'dır. Onunla karşılaşma yaşayan özne ise, yine bir hoşnutluk ya da hoşnutsuzluk temelinde bir alımlama faaliyetinde bulunacaktır. Dolayısıyla burada da özne, tıpkı doğa nesnelerinde olduğu gibi, beğeni yargıları temelinde hareket eder. Nesneye ondan bir çıkar gütmeden ve bilgi edinme amacı olmadan estetik bir hazzı deneyimlemek adına yaklaşma biçimi de estetik yaşantıdan başka bir şey değildir.

Diğer bir Alman filozof Hegel'e göreyse Kant, 'güzel'i evrensel geçerliliği olan bir idea olarak kuramamış, özne ile nesne arasına indirgemiştir. Hegel, eksik bir bilme biçimi olarak sanatı tekrar bilgi kuramına sokmuştur. Ona göre güzel, bir beğeni yargısı değildir; hakikattir; kavramdır, ideadır. Güzel, nesnenin bir niteliğidir. Böyle olunca da nesnel estetik yargılardan söz edilebilir. Bütev, Hegel'in Kant'a itirazı noktasında şunları söyler: Eğer, Kant'ta olduğu gibi, sanatın dile getirilemez olanı gösterme gibi bir gücü var ise, estetik, teorik aklın sınırlarını aşan bir noktaya erişiyor. Hegel'in, sanatın sonunu ilan etmeye kadar giden itirazı, belki de teorik aklı tekrar ön plana çıkarma isteğinden ötürüdür.

Özetle Bütev, kitabının ilk bölümde estetiğin, özerk bir alan olarak kurulma çabalarını ve başta bilgi kuramının içerisinde yer alıp, sonrasında özerk bir alana sahip olabilme, Hegel ile birlikteyse tekrar bilgi kuramı içerisine dönüşünün serüvenini anlatmaktadır.

Çalışmanın ikinci bölümünde ise sanat ve sanat ontolojisi üzerine görüşlere yer verilmiştir. Bölümün başında şu ayrım yapılır; estetik bağlamında doğa ve sanat ayrımı yapmadan dünyanın duyumsal olarak özümsenmesini; beğeni, güzel, yüce, hoşlanma, çirkin vs. meselelerini kapsayan bir 'estetik olgular felsefesi' vardır (birinci bölümde anlatılan 
buydu); bir de sadece sanatı ve sanattaki güzelliği konu edinen, sanatın tanımını yapan, onu türlere ayırarak sınıflandıran, doğasını ve işlevlerini araştıran, onun estetik değerini yapıtın özelliklerinden yola çıkarak saptamaya çalışan 'sanat felsefesi' vardır. Çalışmanın ikinci bölümü, bu ikincisi ile ilgilidir.

Yazar, önce sanat üzerine modern görüşler üzerinde durur. Sanat eserinin temsil ettiği ile değil, biçimiyle etkide bulunduğunu savunan, sanatın anlamlı bir biçim olduğuna dair Clive Bell'in görüşüne yer verir ilk olarak. Ardından, Marksist düşünür Lukacs'ın, sanatın bir yansıtma olduğu yönündeki sanat anlayışına değinir. Lukacs'a göre, sanat gerçeği olduğu gibi taklit etmemeli, insanın türsel kendiliğinin bilincine ulaşmasını sağlayacak misyonu edinmelidir. Ancak gerçekçi yapıtlar, gerçeği çarpıtmadan insanı ve toplumu olduğu gibi betimleyebilir. Toplumcu gerçekçi, kapitalizme karşı cephelerden birisi; angaje ve politik bir sanattır. Adorno ise, sanatı 'burjuva toplumunun yanlışlığından kurtarılmış bir sı̆̆ınak' olarak görür. Greenberg, Deleuze ve Goldmann gibi düşünürlere göreyse, sanat bir icattır. Sanatı taklit olarak görmezler. Onlara göre sanat, hayatın daha önce görülmemiş, yeni bir biçimde duyumsanmasına yol açar. Ressam Kandinski ve Suzanna Langer ise sanatın bir dışavurum, duyguların bir ifade biçimi olduğunu söylerler. Onlara göre, sanat tinselliğin ifadesidir. Bazı düşünürlere göreyse sanat salt imgelemdir. Bu düşünürlerden Collingwood'a göre, sanat eseri, gerçekliğe en sadık kaldığı anda dahi kurmacadır; imgelerle örülmüştür; gerçek dışıdır. Sartre'a göreyse, sanat eseri kendinden başka bir şeye gönderme yapmaz; kendi içinde bir dünyadır. Sanatsal nesne gösterge değildir; dil ya da temsil olarak ele alınamaz; otonom bir özelliğe sahiptir.

Bu görüşlerin ardından, ikinci bölümün sonunda yazar, Nicolai Hartmann'ın sanat ontolojisine yer vermiştir. Hartmann'a göre sanat, var olmayan bir şeyin yaratılmasıdır. Sanatçı, bir nesneyi maddi bir formda ifade ederek onu estetik bir nesneye, bir sanat eserine dönüştürür. Sanat yapıtı, sanatçının nesneyi kendi perspektifinden görüp ona ifade kazandırdığı formdur. Böylece her sanat yapıtı, tinsel ya da zihinsel bir ifade biçimidir. Her sanat yapıtının bir ön yapısı bir de arka yapısı vardır. Ön yapı, görünüş, biçim vs. ile ilişkili maddi yapıdır ve herkesçe duyumsanabilir, doğrudan bir alandır. Arka yapı ise, anlam tabakasıdır ve doğrudan algılamaya açık değildir; sadece, estetik bilgi ve yetiyle onu değerlendirebilecek olanlara açıktır. Dolayısıyla bir sanat yapıtı, kendisini estetik bir nesne olarak kurabilmek için, onu estetik olarak değerlendirebilecek bir kişinin varlığına ihtiyaç duyar. Buna kavrayıcı tin denmektedir. Kavrayıcı tinin varlığı sayesinde, artık herhangi bir nesne değil, estetik nesnedir.

Kitabın üçüncü bölümünde ise, sinema ve estetik üzerine ortaya konan görüşlere ve ardından da Gilles Deleuze'ün zaman-imge kavramına yer verilmiştir. Bütev, seyircinin deneyiminin estetik bir deneyim olduğunu söyler. Ona göre sinema ışığın sanatıdır; kameranın olanaklarıyla gösterir, hatta dile getirilemeyeni gösterir; görüntüyle imgeler. Yeni bir duyumsama biçimi yaratır. Duyulur evrenin boyutlarını, kameranın olanaklarıyla genişleterek, düşünme biçimlerini de dönüştürür ve böylece aslında yeni bir bilinç biçimi yaratır.

Sinemanın ilk yıllarında, henüz sanat olup olmadığı meselesi hakkındaki tartışmalar sürerken, sinemanın sanat olduğunu savunan kuramcllar, temelde biçimci ve gerçekçi kuramcılar olmak üzere ikiye ayrılmışlardır.

Biçimcilere için, sinema gerçekliğin mekanik bir kopyasını üretmekle yetinirse, sanat olarak kabul edilemez. Onlara göre sinema, fiziksel bir gerçekliği yeni bir biçimde duyumsatabildiği ölçüde estetik işlevini yerine getirir. Munsterberg 'e göre, imgeleyen zihindir; aygıt imgelemenin malzemesini sunar. Aygıt, zihnin tasarımladığı imgeleri kaydetme aracıdır. Film perdede değil, seyircinin zihninde oynar. Film kendisini, seyircinin zihninin imgeleme yetisine sunar. Estetik nesnenin, gerçek ya da gerçek dışı olmasının bir önemi yoktur. İmgeler zihinde iz bırakır; bu izler estetik idealara dönüşme potansiyeline sahiptir ve bu gerçekleştiğinde zihinde düşünsel bir etkinliğe yol açar. Filmin estetik değeri buna karşılık 
gelir. Başka bir biçimci olan Arnheim için, kameranın sınırlılıkları, sinemayı sanat yapan en temel unsurdur. Görüş açısının, normal gözün algısına göre kısıtlı oluşu, üç boyutlu şeylerin iki boyutlu bir zemine kaydedilmesi, farklı çekim tarzları vs. yepyeni deneyimler sunar. Bu işlem estetik bir müdahaledir ve bu yüzden de sinema bir sanattır. Yönetmen ve düşünür Eisenstein 'a göreyse sinema, ortaya duygu koymayı değil, seyircide duygu ve etki yaratmayı, onları harekete geçirmeyi amaçlamalıdır. Filmler bu şekilde tasarlanmalıdır.

Gerçekçiler ise, sinemanın hem gerçekliği kayıt ve ifşa edici niteliğine hem de onun fark edilmeyen katmanlarını gösteren bir aygıt olarak üstünlüğüne odaklanmışlardır. Kracauer, eserlerinde sinemanın bu fiziksel gerçekliği kaydetme ve ifşa etme işlevi üzerinde bir hayli durmuştur. Ona göre, sinema bu sayede, bireylerin yitirmiş oldukları, hayatla kurdukları somut deneyimi, hayatın somut imajlarını ortaya koyarak onlara geri vermektedir. Bazin'e göre, sinemada gerçekçilik, gerçek dünyayı olduğu haliyle perdeye yansıtmadır. Ancak sinema, kurgu, alan derinliği gibi uygulamalardan ötürü gerçeğin yanılsamasını ortaya koyar. Sinema, hiçbir sanatın yapamayacağı kadar gerçekliğin katmanlı yapısını ortaya koyabiliyor olsa da, yine de bir yanılsama sanatıdır.

Bütev, sinemanın gerçek ile hayalin, idea ile biçimin bir arada olduğu bir sanat olduğunu söyler. Filozof Gilles Deleuze, bunu fark etmiştir. Bu doğrultuda yazar son olarak, Deleuze'ün sinemaya dair yarattığ 1 kavramlardan birisi olan zaman-imge kavramının üzerinde kisaca durur. Zaman-imge, insanın imgelemiyle birlikte, zihinsel/tinsel gerçeklik alanını da yetkin bir biçimde ortaya koyabilmesiyle söz konusu bir aradalığı sağlamaktadır.

Görüldüğü gibi, tarih boyunca estetik ve sanat üzerine, birbiriyle mücadele eden görüşler öne sürülmüştür. Ancak sinemada, bu çekişen görüşlerin her birinin bir karşıllı̆ı olsa gerek. Bu noktada son sözü yazara bırakalım: "Öyle görünüyor ki sinemayla birlikte duyumla düşünce barışmış, estetik idea kendisine uygun bir mecra bulmuştur". 